\title{
Estimation of Carbon Stock for some Tree Species and Soil in Serabioum Plantation
}

\author{
Nashwa H. Mohamed ${ }^{1}$, and Hany El Kateb ${ }^{2}$
}

\begin{abstract}
Field experiment was carried out at Serapium plantation that irrigated with treated sewage water, to study the productivity and carbon stock of three of the most wide planted tree species in Egypt, Corymbia citriodora, Khaya senegalensis and Casuarina equisetifolia aged 5,11 and 7 years old, within a close range of total height and dbh in 2013. Results showed that one feddan of Khaya senegalensis or Casuarina equisetifolia gave the same amount of total stored carbon (tree biomass, litter layer and soil organic carbon) 34.7 and 34.4 Ton C/feddan. While, one feddan of Corymbia citriodora gave 15.8 ton $\mathrm{C}$. the highest annual increment of growing volume, biomass and stored carbon were recorded in Casuarina equisetifolia followed by Corymbia citriodora While, Khaya senegalensis had the lowest value. Main stem volume can be used to predict stored carbon in tree biomass with a high correlation coefficient $\left(R^{2}\right)$. Also, both of root/shoot ratio (R) and biomass expansion factor (BEF) were calculated to estimate standing trees biomass.
\end{abstract}

Key words: Carbon stock, BEF, Root/ Shoot ratio, Biomass, Corymbia citriodora, Khayasenegalensis and Casuarinaequisetifolia.

\section{INTRODUCTION}

Forests play an important role in global carbon cycle, because of their large pools of carbon. So, accurate estimation of forest biomass is required for greenhouse gas inventories and soil carbon accounting. Therefore, reporting carbon stocks and stock changes based on accurate surveying methods for the Kyoto Protocol is needed. (IPCC, 2003; Krankinaet al., 2004; Patenaudeet al., 2005; UNFCCC, 1997).

Carbon credits on the United Nation's programs for Global Reforestation and Reducing Emissions from Deforestation and Forest Degradation

Depends on the accuracy of carbon stock estimates (Gibbs et al., 2007; Canadell and Raupach, 2008).That for forests have the majority of the global vegetation biomass (Klein Goldewijk, 2001).The global forests cover 3870 million ha according to FRA 2000 ,contains 386 billion cubic meters of wood of a total standing volume. While, woody vegetation stock estimated by 422 billion tons dry matter above-ground biomass of stems, branches, tops and foliage (FAO 2001).

\footnotetext{
${ }^{1}$ Agricultural Research Center, Horticulture Research Institute, Forestry and wood Technology Department, Antoniades Gardens, Alexandria, Egypt.

${ }^{2}$ Institute of Silviculture, Technische Universität München

Received May 21, 2017, Accepted June 19, 2017
}

Carbon stock changes in the forest areas according to annual variation in net primary production and soil respiration, that resulting from climatic variation (Ciais et al. 2005). Therefore, in the last few years the interest of the quantification of the forest ecosystems biomass and its potential carbon fixation were increased (Chave et al., 2005; Fearnside, 1996; Schulp et al., 2008; Sierra et al., 2007). Where, total global carbon in soils ranged between 1500 and 2000 Gtons; as forest biomass stored the majority of it (Janzen, 2004; Smith, 2004).

For calculating biomass, carbon stock, stem volume converted to biomass components (foliage, branches, stem and roots of different sizes) with biomass expansion factor (BEF), (Lehtonen et al. 2004). Tree biomass is the main component of the carbon stock of vegetation, but the understory vegetation especially litter may play an important role (Muukkonen et al. 2006).

Biomass expansion factor is the ratio of the dry weight of the aboveground biomass (stem, foliages, branches and twigs) to main stem volume, (Lehtonen et $a l, 2004)$.that used to convert merchantable stem wood volumes $\left(\mathrm{m}^{3} / \mathrm{ha}\right)$ to total biomass carbon values $(\mathrm{Mg} \mathrm{C} /$ ha) which can be used to estimate carbon budgets (Fukuda et al. 2003; Kilbride et al. 1999). While, root : shoot ratio $(R)$ is commonly used to convert standing volumes of timber into total carbon stocks, for the purpose of national inventories of greenhouse gas emissions and sequestration (Levyet al. 2013).

Using a carbon fraction of 0.50 is problematic because carbon values that have been directly measured range from about 0.45 to 0.55 (Lamlom and Savidge 2003). Tree biomass is multiplied by a carbon fraction to estimate the mass of carbon contained in that tree. Species-specific values of carbon fraction are not widely available and therefore a generalized value of 0.50 is typically used (Brown 2002; Goodale, et al., 2002; Harmon et al. 1990; Pacala et al. 2001; Van Deusen and Roesch 2011).

At the local level, Egypt is one of the countries with the lowest forest cover (70,000 ha). Except a few natural forests in Egypt like mangroves that can be found along the Red Sea, almost all of the planted forests have been established on marginal lands and irrigated with treated 
waste water. These forest plantations are an important means to store carbon in the soil and plant tissue and combat desertification trends (FAO, 2012).

Corymbia citriodora, Khaya senegalensis and Casuarina equisetifolia are fast growing trees in Egypt, planted in large area at different plantations. Serapium plantation is an example of successful plantation and the growth rate of these species were $31.6\left(\mathrm{~m}^{3} / \mathrm{ha}\right), 102.5$ $\left(\mathrm{m}^{3} / \mathrm{ha}\right)$ and $25.0\left(\mathrm{~m}^{3} / \mathrm{ha}\right)$, respectively (FAO, 2012).

A little is known about trees growth, biomass and stored carbon at established plantations in Egypt .where, woody trees have the ability to store a large amount of atmospheric $\mathrm{Co}^{2}$. So, this study aims to build a database including trees productivity of biomass and carbon stock of above \& underground tree components, annual growing stock, Biomass expansion factor (BEF) and root/shoot ratio $(R)$ of each tree species and Organic carbon content of litter layer and soil under the studied species.

\section{MATERIALS AND METHODS}

\section{1-Study area and tree species:}

This study was carried out in November 2013 in Serapium plantation that located in northeastern Egypt $30^{\circ}, 29^{\prime}, 15.55^{\prime \prime} \mathrm{N}$, and $32^{\circ}, 14^{\prime}, 25.43^{\prime \prime} \mathrm{E}$, within the governorate of Ismailia, roughly $16 \mathrm{~km}$. south of Ismailia town and next to the Suez Canal and Serapium village .Plantation area is 373.3 feddan, planted with 10 tree species (FAO, 2012) .

In this study, three tree species that planted at large area and showed fast and good growth rate were selected to calculate their component biomass and carbon stock (Table 1).

\begin{tabular}{lccc}
\multicolumn{4}{l}{ Table 1. Tree species and planted area } \\
\hline Tree species & $\begin{array}{c}\text { Age } \\
\text { (years) }\end{array}$ & $\begin{array}{c}\text { Planting } \\
\text { Area } \\
\text { (feddan) }\end{array}$ & $\begin{array}{c}\text { Planting } \\
\text { Space } \\
\text { (m) }\end{array}$ \\
$\begin{array}{l}\text { Crombya } \\
\text { citriodora }\end{array}$ & 5 & 12 & $3 * 3$ \\
$\begin{array}{l}\text { Khaya } \\
\text { senegalensis } \\
\text { Casuarina } \\
\text { equisetifolia }\end{array}$ & 11 & 13.44 & $3 * 3$ \\
\hline
\end{tabular}

\section{2 - Experimental design:}

A sample of 9,8 and 7 trees were selected randomly of Corymbia citriodora, Khaya senegalensis, and Casuarina equisetifolia, respectively. Then trees were cut down, and extract their root system. Main stem of each tree was cut into logs at $10 \%, 30 \%, 50 \%, 70 \%$, $90 \%$ of tree's total height for volume and biomass calculation. Tree crowns and roots were separated. Stem logs, crown and root system fresh weight was taken, then they dried at $70 \mathrm{C}^{\circ}$ and weighted when reached a constant weight.

\section{3- Above\& below ground biomass and carbon calculation:}

\section{-Biomass}

Main stems were cut into logs then their fresh and dry weight were taken. Also, crown branches were separated, dried and weighted. Both of coarse and fine roots were collected, cut, dried and weighted.

1-Above ground biomass $=$ crown dry weight $(\mathrm{kg})+$ stem dry weight $(\mathrm{kg})$.

2-Below ground biomass $=$ root system dry weight $(\mathrm{kg})$.

3-Total tree biomass $(\mathrm{kg})=$ above ground biomass + below ground biomass.

4-Biomass of total area $=$ main of total tree biomass $(\mathrm{kg})$ * trees number / feddan*planted area (feddan) +litter layer biomass.

- Carbon:

1.Stored carbon $(\mathrm{kg})=$ Biomass of total area $(\mathrm{kg}) * 0.5$ (Brown and Lugo, 1984).

2. Stored $\mathrm{Co}_{2}(\mathrm{~kg})=$ stored $\mathrm{C}(\mathrm{kg}) * 3.67$

3.Stored $\mathrm{Co}_{2}$ metric tons $=$ stored $\mathrm{Co}_{2}(\mathrm{~kg}) * 0.001$ (Nowak, 1994)

\section{4- Tree volume measurements \& equations:}

For each felling tree total and commercial height, diameter over bark at dbh and at 0,10, 20, 30, 50, 70, $90 \%$ of tree total height, diameter at eight directions of crown (m) and crown length (m), depth and diameter of root system zone were measured.

-Volume of each $\log (\mathrm{V})$ was calculated with Smalian equation according to this formula:

$$
V=\frac{g_{1}+g_{2}}{2} \mathrm{~h}
$$

Where: $\mathrm{g}_{1}, \mathrm{~g}_{2}$ is bottom and top log basal area $\left(\mathrm{m}^{2}\right), \mathrm{h}$ is $\log$ height ( $\mathrm{m})$ (Gray, 1956).

-Upper part of stem was calculated as a cone according to next equation: $V=(1 / 3) \pi r^{2} h$

Where: $\mathrm{h}$ is a $\log$ height $(\mathrm{m}), \mathrm{r}$ is a $\log$ base radius.

\section{5 -Trees density:}

Number of living trees with $\mathrm{dbh} \geq 5 \mathrm{~cm}$ were counted at feddan.

\section{6- Litter layer}

For each tree species three ground samples of $\left(1 \mathrm{~m}^{2}\right)$ area were measured then all fall litters (dead leaves and twigs) within this area were collected, dried at $70 \mathrm{C}^{\circ}$ and weighted when reached a constant weight. 


\section{7- Root/Shoot ratio ( $R$ )}

Root/Shoot ratio was calculated using the following equation.

$\mathrm{R}=\mathrm{BGB} / \mathrm{AGB}$ (Sanquetta et al., 2011)

Where: $\mathrm{R}$ is root/shoot ratio,

BGB: oven dry weight of root $(\mathrm{kg})$

AGB: oven dry weight of above ground components of tree $(\mathrm{kg})$.

\section{8- Biomass Expansion Factor ( BEF)}

Biomass expansion factor calculated by divide dry weight of the above ground biomass (stem, foliages, branches and twigs) to main stem volume, as following equation.

$\mathrm{BEF}=\mathrm{W} / \mathrm{V}$ (Lehtonen et al, 2004).

Where: $\mathrm{W}$ is the dry weight of above ground biomass $(\mathrm{kg})$

$: \mathrm{V}$ is the volume of main stem $\left(\mathrm{m}^{3}\right)$.

\section{9 - Soil organic carbon}

Three replicates of soil samples were taken at different depth 0-10, 10-60 and 60-120 cm from each tree species stand, to calculate soil bulk density, organic matter $\%$ and organic carbon according to this equation: The carbon stock of soil organic carbon (Soc) calculated as (Pearson et. al 2007):

$$
\mathrm{Soc}=p * \mathrm{~d} * \mathrm{C} \%
$$

where,

Soc $=$ soil organic carbon stock per unit area,

$P=$ soil bulk density $\left[\mathrm{g} \mathrm{cm}^{-3}\right]$,

$\mathrm{d}=$ the total depth at which the sample was taken $[\mathrm{cm}]$, and

$\mathrm{C}=$ carbon concentration [\%].

\section{0 - Wood density}

Samples along tree stems were cut into regular geometric forms to calculate their volume, then oven dried at $103 \pm 2 \mathrm{c}^{0}$ to a constant weight. Wood density calculated according to this formula:

$$
\text { Wood density }=\frac{\text { dried weight }}{\text { volume }}
$$

\section{1- Statistical analysis}

Mean, standard divisions, coefficient of variation (C.V) were calculated for results. Also, a simple linear regression analysis was used to test the significantly between tree volume, biomass and carbon content of tree components according to (Snedecor and Cochran, 1974).

\section{RERSULTS AND DISCUSSION}

Khaya senegalensis and Casuarina equisetifolia with the same dbh and total height rang $10-23 \mathrm{~cm}, 8.4-$ $15 \mathrm{~m}$ and $10.5-22 \mathrm{~cm}, 8.5-16 \mathrm{~m}$. with mean dbh $15.4 \mathrm{~cm}$, $12.53 \mathrm{~cm}$ and mean total height $12.1,15.5 \mathrm{~m}$, respectively. While, Crombya citriodora with dbh rang $8.8-16 \mathrm{~cm}$ and $16.46 \mathrm{~cm}$ mean, total height rang 10.5 $19.3 \mathrm{~m}$ and $11.97 \mathrm{~m}$ mean were studied to calculate their biomass productivity and stored carbon per feddan. Means of tree characteristics were summarized in (Table 2).

\section{1-Tree components biomass}

Above ground biomass of Crombya citriodora, Khaya senegalensis and Casuarina equisetifolia species were calculated using both stem and crown dry weight $(\mathrm{kg})$ while, fine and coarse roots dry weight were used as below ground biomass .Results indicated that mean values of above ground biomass were $73.03 \pm 13.9$, $131.87 \pm 17.5$ and $117 \pm 24.6 \mathrm{~kg}$. while, the mean values of below ground biomass were $20.4 \pm 4,40.75 \pm 5.5$ and $35.34 \pm 6.7 \mathrm{~kg}$, for the three species respectively. Total tree biomass calculated using sum of above and below ground biomass and recorded $94 \pm 16.16,173.2 \pm 32$ and $153.3 \pm 25.23 \mathrm{~kg}$. for the three species, respectively (Table3). Results showed that Khaya senegalensis had the highest means of above, below and total biomass followed by Casuarina equisetifolia. while, Crombya citriodora had the lowest value. Result was agreeable with Warnasooriya and Sivananthawerl (2016) where, total biomass of Khaya senegalensis 11-12 years old was (170.18 kg). Also, Faming et al. (2013) mentioned that above, below and total biomass increased markedly with stand age on C. equisetifolia plantations.

\section{2- Stored carbon:}

Biomass of total tree, tree components above and below ground $(\mathrm{kg})$ were converted to $\mathrm{C}$ content $(\mathrm{kg})$ by multiplied to 0.5 factor. Results presented in table (3) showed that stored carbon in above and below ground and in total biomass of Crombya citriodora were 36.47 $\pm 7.6,11.8 \pm 1.9$ and $48.4 \pm 6.13 \mathrm{~kg}$, respectively, while Khaya senegalensis were $65.96 \pm 12.7,20.48 \pm 3.1$ and $86.4 \pm 15.36 \mathrm{~kg}$. when, Casuarina equisetifolia recorded $58.8 \pm 10.4,17.9 \pm 3.5$ and $76.66 \pm 13.8 \mathrm{Kg}$, in order, (Table 3). De Costa and Suranga (2012) found that the mean C stock (t / ha) for Eucalyptus citriodora 86.81, however, it was 27.38 for Casuarina spp. Swamy et al.(2011) explain The variation in carbon stock values due to variation in the biomass production capacity of species related to growth habit of the species. Generally high $\mathrm{C}$ stock and productivity, depends on higher above ground biomass (AGB) in long rotation forests compared to short one. Accurate quantification of carbon stocks of the forests required local information 


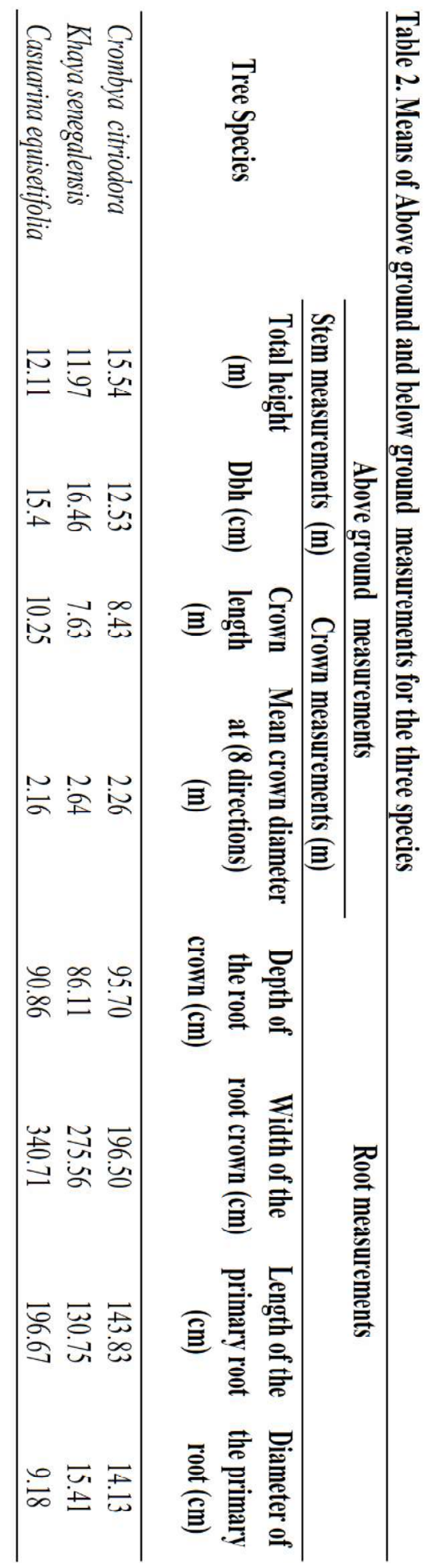


Table 3. Means and statistical analysis of trees growth parameters and product

\begin{tabular}{|c|c|c|c|c|}
\hline Analysis & Mean & M.S & S D & $\mathbf{C V}$ \\
\hline \multicolumn{5}{|c|}{ Corymbia citriodora } \\
\hline volume $\left(\mathrm{m}^{3}\right)$ & 0.12 & 0.0004 & \pm 0.02 & $15 \%$ \\
\hline Stem biomass (kg) & 58.15 & 109.6 & \pm 10.5 & $18 \%$ \\
\hline Crown biomass $(\mathrm{kg})$ & 14.85 & 10.17 & \pm 3 & $20 \%$ \\
\hline Above ground biomass (kg) & 73.03 & 194.4 & \pm 13.9 & $19 \%$ \\
\hline Below ground biomass $(\mathrm{kg})$ & 20.4 & 16.4 & \pm 4 & $19.6 \%$ \\
\hline Total tree biomass $(\mathrm{kg})$ & 94 & 261.2 & \pm 16.16 & $17 \%$ \\
\hline Root/ shoot ratio ( $\mathrm{R}$ ) & 0.26 & 0.001 & \pm 0.03 & $11.5 \%$ \\
\hline Biomass Expansion Factor (BEF) & 0.73 & 0.01 & \pm 0.1 & $13.4 \%$ \\
\hline Wood density $\left(\mathrm{g} / \mathrm{cm}^{3}\right)$ & 0.60 & 0.001 & \pm 0.03 & $5 \%$ \\
\hline Stored Carbon in above ground tree $(\mathrm{Kg})$ & 36.47 & 50.84 & \pm 7.6 & $20.8 \%$ \\
\hline Stored Carbon in Below ground tree $(\mathrm{Kg})$ & 11.8 & 3.46 & \pm 1.9 & $16 \%$ \\
\hline Stored Carbon in total tree $(\mathrm{Kg})$ & 48.4 & 37.6 & \pm 6.13 & $12.65 \%$ \\
\hline Dry weight of litter layer $\mathrm{g} / \mathrm{m} 2$ & 56 & 36 & \pm 6 & $11 \%$ \\
\hline Carbon content of litter layer $\mathrm{kg} /$ area feddan & 1411 & 10000 & \pm 100 & $7 \%$ \\
\hline \multicolumn{5}{|c|}{ Khaya senegalensis } \\
\hline volume $\left(\mathrm{m}^{3}\right)$ & 0.16 & 0.001 & \pm 0.03 & $19 \%$ \\
\hline Stem biomass $(\mathrm{kg})$ & 71.23 & 184.2 & \pm 13.6 & $19 \%$ \\
\hline Crown biomass (kg) & 60.29 & 201.8 & \pm 14 & $23 \%$ \\
\hline Above ground biomass (kg) & 131.87 & 317.7 & \pm 17.5 & $13.3 \%$ \\
\hline Below ground biomass $(\mathrm{kg})$ & 40.75 & 30.8 & \pm 5.5 & $13.5 \%$ \\
\hline Total tree biomass $(\mathrm{kg})$ & 173.2 & 1023 & \pm 32 & $18.5 \%$ \\
\hline Root/ shoot ratio (R ) & 0.32 & 0.004 & \pm 0.06 & $18.6 \%$ \\
\hline Biomass Expansion Factor (BEF) & 0.92 & 0.03 & \pm 0.17 & $18.6 \%$ \\
\hline Wood density $\left(\mathrm{g} / \mathrm{cm}^{3}\right)$ & 0.51 & 0.002 & \pm 0.04 & $7.8 \%$ \\
\hline Stored Carbon in above ground tree $(\mathrm{Kg})$ & 65.96 & 161 & \pm 12.7 & $19 \%$ \\
\hline Stored Carbon in Below ground tree $(\mathrm{Kg})$ & 20.48 & 9.6 & \pm 3.1 & $15 \%$ \\
\hline Stored Carbon in total tree $(\mathrm{Kg})$ & 86.4 & 236.01 & \pm 15.36 & $17.8 \%$ \\
\hline Dry weight of litter layer $\mathrm{g} / \mathrm{m} 2$ & 122 & 126 & \pm 11 & $9 \%$ \\
\hline Carbon content of litter layer $\mathrm{kg} /$ area feddan & 3443 & 146689 & \pm 383 & $11 \%$ \\
\hline \multicolumn{5}{|c|}{ Casuarina equisetifolia } \\
\hline volume $\left(\mathrm{m}^{3}\right)$ & 0.13 & 0.0004 & \pm 0.02 & $15 \%$ \\
\hline Stem biomass (kg) & 75.19 & 183.5 & \pm 13.5 & $18 \%$ \\
\hline Crown biomass (kg) & 43.4 & 57.8 & \pm 7.6 & $17.5 \%$ \\
\hline Above ground biomass $(\mathrm{kg})$ & 117.4 & 605 & \pm 24.6 & $21 \%$ \\
\hline Below ground biomass $(\mathrm{kg})$ & 35.34 & 44.33 & \pm 6.7 & $19 \%$ \\
\hline Total tree biomass $(\mathrm{kg})$ & 153.3 & 636.5 & \pm 25.23 & $16.5 \%$ \\
\hline Root/ shoot ratio $(\mathrm{R})$ & 0.29 & 0.01 & \pm 0.06 & $20.7 \%$ \\
\hline Biomass Expansion Factor (BEF) & 1.03 & 0.03 & \pm 0.16 & $15.5 \%$ \\
\hline Wood density $\left(\mathrm{g} / \mathrm{cm}^{3}\right)$ & 0.59 & 0.001 & \pm 0.03 & $5 \%$ \\
\hline Stored Carbon in above ground tree $(\mathrm{Kg})$ & 58.8 & 108.8 & \pm 10.4 & $17.7 \%$ \\
\hline Stored Carbon in Below ground tree $(\mathrm{Kg})$ & 17.9 & 13.1 & \pm 3.5 & $19.7 \%$ \\
\hline Stored Carbon in total tree $(\mathrm{Kg})$ & 76.66 & 191.25 & \pm 13.8 & $18 \%$ \\
\hline Dry weight of litter layer $\mathrm{g} / \mathrm{m} 2$ & 61 & 42 & \pm 6.5 & $11 \%$ \\
\hline Carbon content of litter layer $\mathrm{kg} /$ area feddan & 492 & 10000 & \pm 100 & $20 \%$ \\
\hline
\end{tabular}


on tree allometry, wood density and species composition, ( Brigitte et al.2016). Where, trees act as $\mathrm{CO}_{2}$ absorber from the atmosphere and store it in the form of wood (Chaturvedi and Khanna, 1984). Thus, absorbing $\mathrm{CO}_{2}$ from air and locking it in the forest biomass is one of the important method to remove large volume of $\mathrm{CO}_{2}$ from the atmosphere.

3-Tree volume (V),root/ shoot ratio ( $R$ ), biomass expansion factor ( BEF) and wood density (d) $\mathrm{g} / \mathrm{cm}^{3}$ :

For calculating biomass of standing trees without cutting them down, main stem volume, wood density and other relations such as $\mathrm{R}$ and BEF are used. As presented in table (3) means of tree volume and (R) increased by increasing trees age. Mean values were $0.12 \pm 0.02,0.13 \pm 0.02$ and $0.16 \pm 0.03 \mathrm{~m}^{3} ; 26 \% \pm 0.03$, $29 \% \pm 0.06$ and $32 \% \pm 0.06$, for Crombya citriodora, Casuarina equisetifolia and Khaya senegalensis ,respectively. While, BEF recorded the highest value by Casuarina equisetifolia (1.03 \pm 0.16$)$, then Khaya senegalensis $(0.92 \pm 0.17)$ and finally Crombya citriodora $(0.73 \pm 0.1)$. while, wood density values were $0.6 \pm 0.03,0.51 \pm 0.04$ and $0.59 \pm 0.03$ for Crombya citriodora, Khaya senegalensis and Casuarina equisetifolia, respectively. Both of wood density value of Khaya senegalensis and Casuarina equisetifolia recorded low values according to Orwa et al.(2009) and FAO (1997) wood density range ( 0.6 to 0.85 ) for Khaya senegalensis and wood density of Casuarina equisetifolia 0.83 according to FAO (1997) and Swamy et al.(2011) while, Crombya citriodora wood density was agreeable with FAO (1997) $0.64 \mathrm{~g} / \mathrm{cm}^{3}$.On other hand, values of volume and wood density of Khaya senegalensis was within range (0.01 to 1.04 $\mathrm{m}^{3} /$ tree $)$ and $\left(0.27\right.$ to $\left.0.76 \mathrm{~g} \mathrm{~cm}^{-3}\right)$ respectively, according to Daniel (2011) on his study on Khaya species. aged 12 years.

Results showed that BEF and $\mathrm{V}$ of Casuarina equisetifolia and Khaya senegalensis recorded high results, while, Crombya citriodora showed opposite trend (Brown and Schroeder 1999 ), also they referred to the significant relation of $\mathrm{BEF}$ and the growing volume for most forest types, where, generally BEF starting high at low volumes and then it decrease to rich a constant low value at high volumes. Also, Yunjian Luo et al. (2013) agreed with this trend, they found that BEF of Casuarina was $1.58 \pm 0.32$ and for Eucalypts was $1.50 \pm 0.20$ in China forests. Thus, that BEF decreased with increasing stand age and size (e.g., dbh, tree height, and standing volume). Also, this result matched with FAO (2012) for Khaya trees during a study at spreamium. Although, Khaya senegalensis recorded the highest volume per hectare $\left(102.5 \mathrm{~m}^{3} / \mathrm{ha}\right)$, it didn't match with annual increment while, Crombya citriodora was the opposite. In case of Casuarina equisetifolia it recorded the highest growth value because it considers one of the superior fast-growing tree species in biomass production. Pongsak- Sahunalu and Wiratana- Tanpibal (1985) found high growth of 12-years old Casuarina trees $16.2 \mathrm{~cm} \mathrm{dbh}$ and $20.3 \mathrm{~m}$ height, also, Swamy et al. (2011) observed superior performance for Casuarina equisetifolia, due to its ability on nitrogen-fixation, so it can grow well on poor and salty soils (CABI 2012).While , ( $R$ ) increased as dbh increased this trend match with, Sohial et al.( 2014). So, BEF and $\mathrm{R}$ are initial information should be calculated to estimate biomass of stand.

\section{4-Annual growing biomass and carbon stock.}

Table (4) presented mean values of annual increment of growth parameters and biomass productivity. Results showed that Crombya citriodora has the highest annual

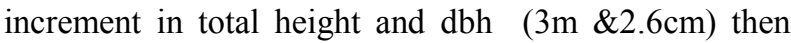
Casuarina equisetifolia (1.6m \&2.1 cm), however, Khaya senegalensis had the lowest values $(1.1 \mathrm{~m} \& 1.6$ $\mathrm{cm})$. where, the highest values of Tree total biomass, carbon stock and growing volume /feddan were recorded by Casuarina equisetifolia, Crombya citriodora and Khaya senegalensis, respectivly. Faming et al. (2013) found That annual accumulation of Carbon in plant biomass of $C$. equisetifolia aged 3-6, 6-13 years old were 8.2 and $4.2 \mathrm{Mg} \mathrm{C}$ ha-1 $\mathrm{yr}^{-1}$, respectively also they mentioned that biomass and carbon accumulation increased markedly with stand age. Also, FAO (2012) found that the best volume increment showed by Eucalyptus citriodora and Khaya senegalensis

\section{5-Soil organic carbon and litter layer:}

Table (5) presented mean values of soil bulk density, organic matter $\%$ and organic carbon under each tree species at different depths. Results showed that the highest values of $\mathrm{OM} \%$ and $\mathrm{OC} \%$ were at the soil upper layer $10 \mathrm{~cm}$ depth. The highest mean of total organic carbon kg/ feddan was observed at soil under Casuarina equisetifolia $(1071.4 \mathrm{~kg})$, then followed by Crombya citriodora $(815.3 \mathrm{~kg})$ while, Khaya senegalensis recorded the lowest value $305.8 \mathrm{~kg}$. Where, litter layers of 7,10 and $15 \mathrm{~cm}$ thickness under species Casuarina equisetifolia, Crombya citriodora and Khaya senegalensis, contained 492, 1411 and $3443 \mathrm{Kg} \mathrm{C} \mathrm{/}$ feddan, respectively ( Table 3 ). 


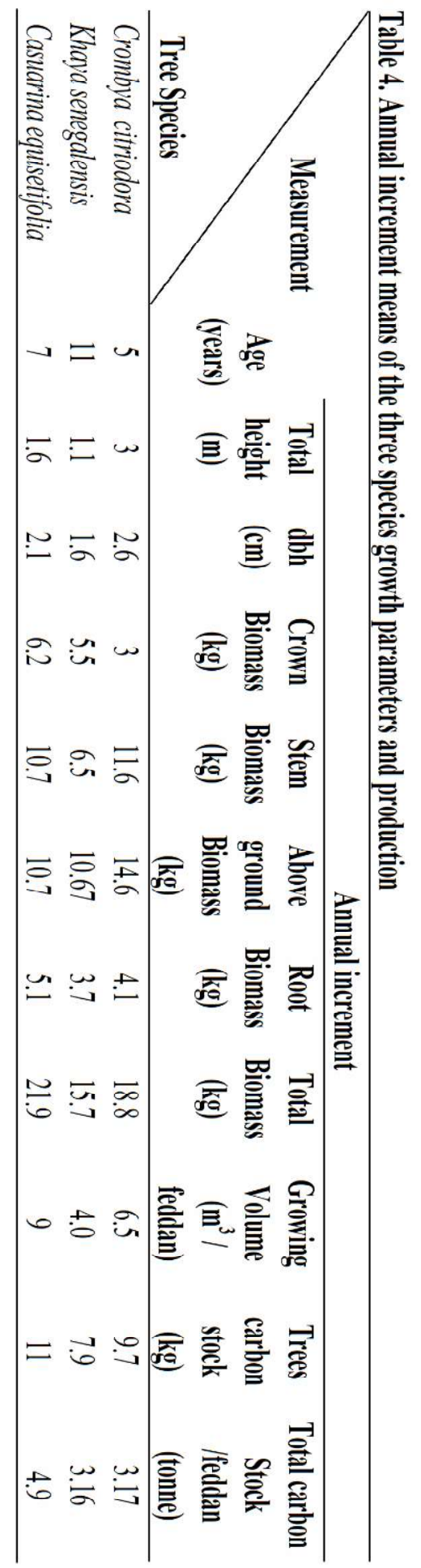


Table 5. Means and statistical analysis of soil characteristics under the tree species

\begin{tabular}{|c|c|c|c|c|c|}
\hline Soil depth & $\begin{array}{c}\text { Bulk density } \\
\mathrm{g} / \mathrm{cm}^{3}\end{array}$ & $\begin{array}{c}\text { Organic } \\
\text { matter } \\
\text { OM \% }\end{array}$ & $\begin{array}{c}\text { Organic } \\
\text { Carbon } \\
\text { OC\% }\end{array}$ & $\begin{array}{l}\text { Total Organic } \\
\text { Carbon } \\
\text { Kg/ feddan }\end{array}$ & $\begin{array}{c}\text { Total Organic } \\
\text { Carbon } \\
\text { Ton/ all area }\end{array}$ \\
\hline Species & \multicolumn{5}{|c|}{ Crombya citriodora } \\
\hline $0-10 \mathrm{~cm}$ & 1.51 & 0.88 & 0.51 & 324.42 & 3.89 \\
\hline $10-60 \mathrm{~cm}$ & 1.29 & 0.34 & 0.31 & 849.02 & 10.19 \\
\hline $60-120 \mathrm{~cm}$ & 1.50 & 0.58 & 0.34 & 1272.33 & 15.27 \\
\hline Mean & 1.43 & 0.67 & 0.39 & 815.3 & 9.78 \\
\hline MS & 0.016 & 0.02 & 0.011 & 225489 & 32.47 \\
\hline SD & \pm 0.13 & \pm 0.14 & \pm 0.1 & \pm 474.9 & \pm 5.7 \\
\hline \multirow[t]{2}{*}{ C.v. } & $9 \%$ & $21 \%$ & $25.8 \%$ & $58 \%$ & $\% 58$ \\
\hline & \multicolumn{5}{|c|}{ Khaya senegalensis } \\
\hline $0-10 \mathrm{~cm}$ & 1.47 & 0.27 & 0.16 & 97.10 & 1.31 \\
\hline $10-60 \mathrm{~cm}$ & 1.52 & 0.19 & 0.11 & 352.28 & 4.73 \\
\hline $60-120 \mathrm{~cm}$ & 1.68 & 0.19 & 0.11 & 468.03 & 6.29 \\
\hline Mean & 1.56 & 0.2 & 0.13 & 305.8 & 4.11 \\
\hline MS & 0.012 & 0.002 & 0.0007 & 36016 & 6.5 \\
\hline SD & \pm 0.1 & \pm 0.04 & \pm 0.03 & \pm 189.8 & \pm 2.5 \\
\hline \multirow[t]{2}{*}{ C.V. } & $7 \%$ & $18.5 \%$ & $20.6 \%$ & $62 \%$ & $60 \%$ \\
\hline & \multicolumn{5}{|c|}{ Casuarina equisetifolia } \\
\hline $0-10 \mathrm{~cm}$ & 1.45 & 0.9 & 0.52 & 317.85 & 1.21 \\
\hline $10-60 \mathrm{~cm}$ & 1.50 & 0.7 & 0.41 & 1282.31 & 4.87 \\
\hline $60-120 \mathrm{~cm}$ & 1.57 & 0.7 & 0.41 & 1613.95 & 6.13 \\
\hline Mean & 1.5 & 0.77 & 0.45 & 1071.4 & 4.1 \\
\hline MS & 0.004 & 0.013 & 0.005 & 453337.8 & 6.5 \\
\hline SD & \pm 0.06 & \pm 0.1 & \pm 0.07 & \pm 673 & \pm 2.5 \\
\hline C.V. & $4 \%$ & $14 \%$ & $15.7 \%$ & $62.8 \%$ & $\% 61$ \\
\hline
\end{tabular}

These results were at the same line with Swamy et al. (2011) in their study on six different tree species included Casuarina equisetifolia, they found a highly significant variation of soil organic carbon may be attributed to amount of litter fall, decomposition, nutrient release to the soil. Also, carbon sequestration potential in soils can be strongly affected by root production and soil microbial activity proportional to inputs of soil organic carbon at the top layers. Accordingly, as the depth increases, the organic carbon was decreased due to low decomposition of organic matter.

\section{6- Predicted trees stored carbon using main stem volume:}

A simple linear regression analysis were used to test the significance between main stem volume and above ground, below ground and total tree biomass stored carbon for Crombya citriodora, Khaya senegalensis and Casuarina equisetifolia. Results showed a highly significant correlation coefficient $\left(R^{2}\right)$ between the main stem volume and stored carbon in above ground, below ground and total tree biomass as shown in Table (6) and Fig (1). Also, stored carbon can be predicted using stem volume according to equations summarized in Ttable (7). This is agreeable with Timothy et al. (2007). Also, Houghton et al. (1999).Where, to get an accurate measurement of carbon pool and fluxes it is necessary to know about the volume of tree and total biomass. Moreover, Peter et al. (2002) described that tree $\mathrm{dbh}$ and volume are more time-consuming and accurate approach can be used to predict wood mass using regression model.

\section{CONCLUSION}

Results showed that Crombya citriodora tree aged 5 years old had $0.12 \mathrm{~m}^{3}$ volume and $126.87 \mathrm{~kg}$ biomass that stored $63.44 \mathrm{~kg}$ carbon and stored 15.8 tone $\mathrm{C} /$ feddan, with annual increment $6.5 \mathrm{~m}^{3}$ of volume and 3.17 tone C/feddan. when, Khaya senegalensis tree aged 11 years gave $0.16 \mathrm{~m}^{3}$ volume, $173.2 \mathrm{~kg}$ biomass and stored $86.4 \mathrm{~kg}$ Carbon. while, it stores 34.7 tone total C / feddan, with $8.11 \mathrm{~m}^{3}$ annual volume increment and 3.16 tone annual stored carbon increment .where's Casuarina equisetifolia tree aged 7 years gave $0.13 \mathrm{~m}^{3}$ volume, $153.3 \mathrm{~kg}$ biomass and stored $76.66 \mathrm{~kg}$ carbon. We can obtain 34.4 tone stored $\mathrm{C} /$ feddan, $9 \mathrm{~m}^{3}$ annual volume increment and 4.9 tone annual stored carbon increment, for Casuarina equisetifolia. 


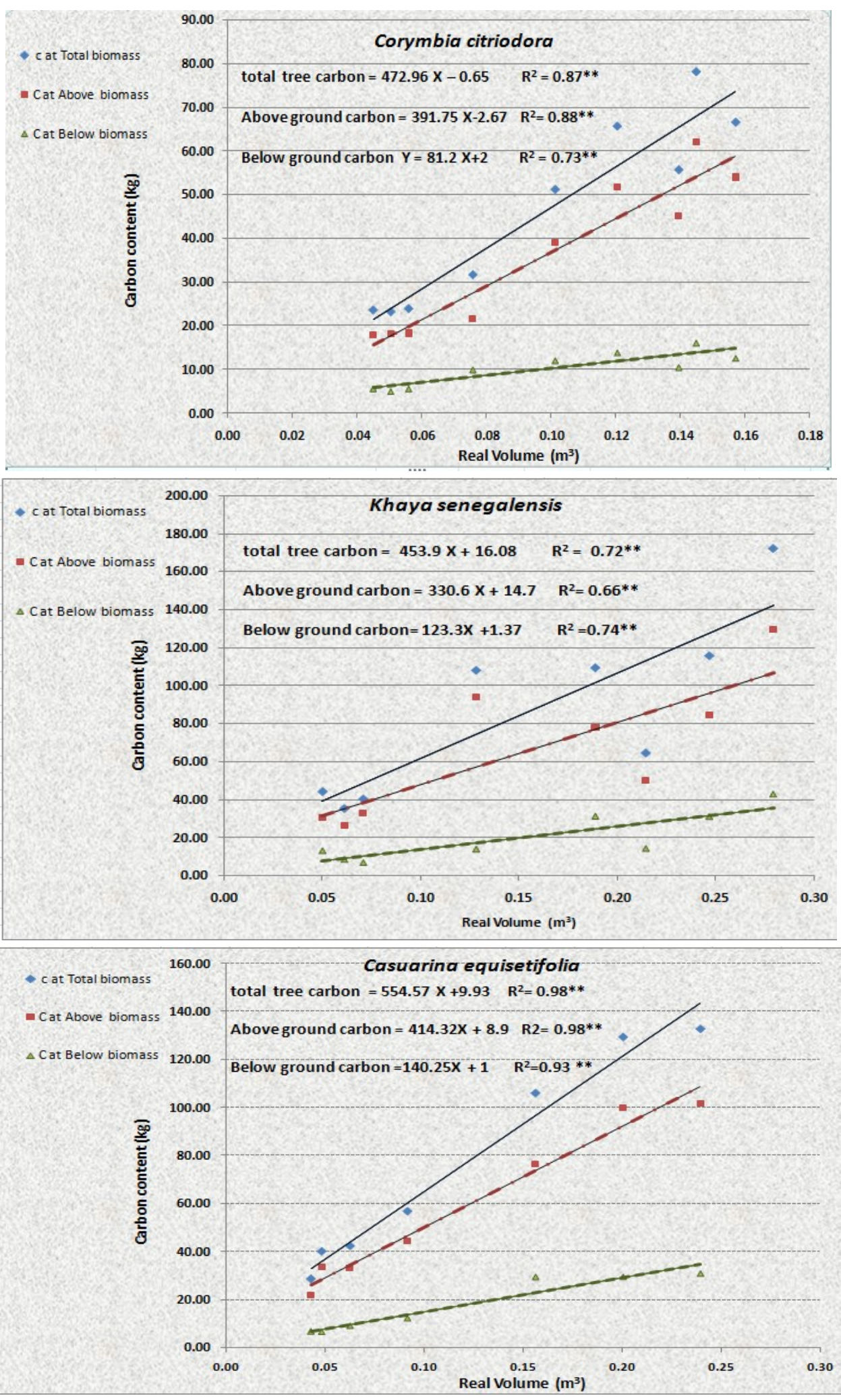

Fig. 1.Regression analysis of the tree stem volume (m3) and carbon stock (kg) 


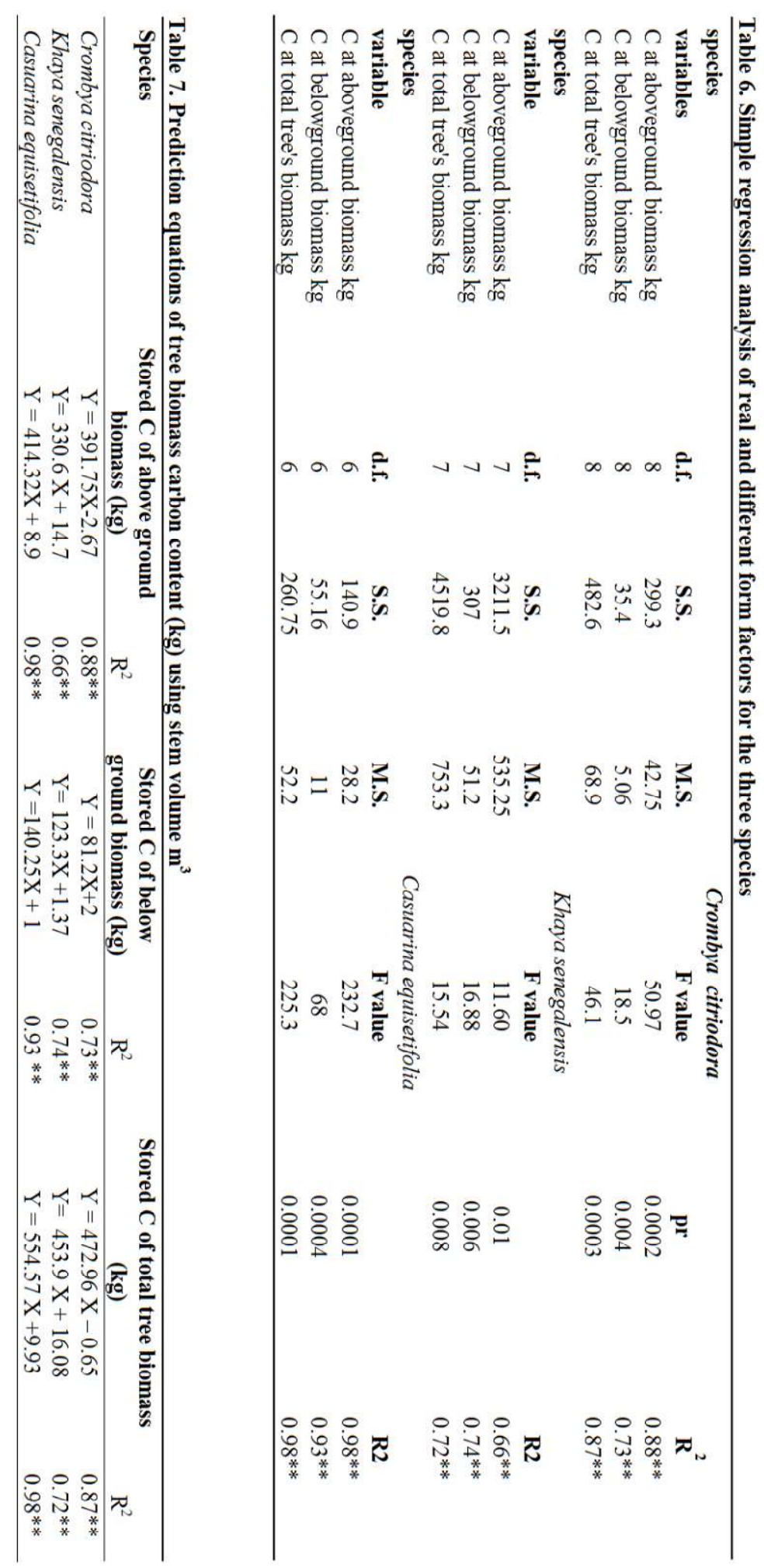


According to the results, it was expected that older trees give the highest volume and biomass. but, Crombya citriodora had the highest annual increment of total high, dbh and above biomass even it's the youngest that's because young trees growing faster in height. While, Casuarina equisetifolia had the highest annual increment of volume, total biomass and carbon stock.

Finally, trees act an important role to store carbon in their tissues and soil, decreasing atmosphere warm and give wood as a main commercial product. Moreover, planting trees using treated sewage water is consider a save way to reuse this water. So, we need to expand planted area of fast growing trees especially, Casuarina equisetifolia and Crombya citriodora.

\section{ACKNOWLEDGMENT}

The authors gratefully acknowledge the members of German-Egyptian Research project "Establishment of plantation forests and Development of sustainable forestry in Desert Lands of Egypt using sewage water" for their contribution in this research.

\section{REFERENCES}

Brigitte, N ., E. Zibera, F. K. Uwizeye, D. Nsabimana, E. Bizuru ,H. Pleijel, J. Uddling, and G. Wallin1. 2016 Carbon stocks and dynamics at different successional stages in an Afromontane tropical forest. Biogeosciences Discuss., doi:10. 5194/bg-353

Brown, S. and A.E. Lugo. 1984. Biomass of tropical forests: a new estimate based on forest volumes. Science 223: 12901293.

Brown, S.L. and P.E. Schroeder.1999. Spatial patterns of above ground production and mortality of woody biomass for eastern US forests.Ecological Applications 9: 968-980.

Brown, S. 2002. Measuring carbon in forests: current status and future challenges. Environmental Pollution 116: 36372

CABI 2012. Forestry Compendium database report Casuarina equisetifolia. http://www.cabi.org/fc/ (06. September 2012).

Canadell, J.G. and M.R. Raupach. 2008. Managing forests for climate change mitigation. Science 320: 1456-1457.

Chaturvedi and Khanna. 1984. Forest Mensuration International Book Distributors, Dehradun. Cited From, Swamy K.R., H. Shivanna, P. Surendra, K.S. Channabasappa and A.G. Koppad. 2011. Carbon stocking through shelterbelt tree species in Haveri District .My Forest, Sep.,47 (3): 175-181.

Chave, J., C. Andalo, S. Brown, M. Cairns, J. Chambers, D. Eamus, H. Folster, F. Fromard, N. Higuchi and T. Kira. 2005. Tree allometry and improved estimation of carbon stocks and balance in tropical forests. Oecologia 145: 8799.
Ciais, P., M. Reichstein, N. Viovy, A. Granier, J. Ogee and V. Allard. 2005. Europe-wide reductionin primary productivity caused by the heat and drought in 2003 . Nature 437: 529-533.

Daniel, Y.2011. Variation in carbon content of tropical tree species from Ghana. Michigan Technological University, Dissertations, Master's Theses and Master's Reports. P.8

De Costa ,W.A.J.M. and H.R. Suranga .2012. .Estimation of carbon stocks in the forest plantations of Sri Lanka. J. Natn. Sci. Foundation Sri Lanka 40: 9-41

Faming, w., X. Xu, B. Zou, Z. Guo, Z. Li and W. Zhu.2013. Biomass Accumulation and Carbon Sequestration in Four Different Aged Casuarina equisetifolia Coastal Shelterbelt Plantations in South China. PLoS ONE 8(10): e77449. doi:10.1371/journal.pone.0077449

FAO. 1997. Estimating biomass and biomass change in tropical forests.

http://www.fao.org/docrep/w4095e/w4095e0c.htm\#Top Of Page

FAO. 2001. Global forest resources assessment 2000. Main report. Food and Agriculture Organizationof the United Nations (FAO). FAO Forestry Paper 140. Rome. 479 p.

FAO .2012. Serapium Forest Ismailia, Egypt: Forest Management Plan 2013-2022. Project working paper 03(GCP/RAB/013/ITA).

Fearnside, P. 1996. Amazonian deforestation and global warming: carbon stocks invegetation replacing Brazil's Amazon forest. Forest Ecology and Management 80: 2134.

Fukuda, M., T .Iehara and M .Matsumoto .2003. Carbon stock estimates for sugi and hinoki forests in Japan. For Ecol Manage 184:1-16

Gibbs, H.K., S .Brown, J.O. Niles and J.A. Foley. 2007. Monitoring and estimating tropical forest carbon stocks: making REDD a reality. IOP Publishing ,Environmental Research Letters 2 (4): 045023. Pp. 13

Goodale, C.L., M.J. Apps, R.A. Birdsey and others. 2002. Forest carbon sinks in the Northern Hemisphere. Ecological Applications 12: 891-899.

Gray, H. R.1956.The Form and taperof forest-tree stems, Imperial Forestry Institute University of Oxford, No. 32 pp 63.

Harmon, M.E., W.K. Ferrell and J.F. Franklin.1990. Effects on carbon storage of conversion of old-growth forests to young forests. Science 247(4943): 699.

Houghton, R.A., J.L, Hackler and K.T. Lawrence.1999. The U.S. carbon budget contributions from land-use change. Science 285:574-578.

IPCC. 2003. Good practice guidance for land use, land-use change and forestry. Hayama, Japan: IPCC National Greenhouse Gas Inventories Programme 295 pp.

Janzen, H. 2004. Carbon cycling in earth systems: a soil science perspective. Agriculture, Ecosystems \& Environment 104: 399-417. 
Kilbride, C.M., K. A. Byrne and J.J. Gardiner .1999. Carbon sequestration and Irish forests. COFORD, Dublin

Krankina, O. N., M. E. Harmon, W. B. Cohen, D. R. Oetter, O. Zyrina and M. V. Duane.2004. Carbon stores, sinks, and sources in forests of Northwestern Russia: Can we reconcile forest inventories with remote sensing results? Climatic Change, 67: 257-272.

Klein Goldewijk, K. 2001. Estimating global land use change over the past 300 years: the HYDE database. Global Biogeochemical Cycles 15: 417-433.

Lamlom, S. H. and R.A. Savidge. 2003. A reassessment of carbon content in wood: variation within and between 41 North American species. Biomass and Bioenergy 25: 381388.

Lehtonen, A., R. Mäkipää, J. Heikkinen, R. Sievänen and J. Liski. 2004. Biomass expansion factors (BEFs) for Scots pine, Norway spruce and birch according to stand age for boreal forests. Forest Ecology and Management, 188: 211-224.

Levy, P.E., S.E. Hale and B.C. Nicoll. 2013. Biomass expansion factors and root: shoot ratios for coniferous tree species in Great Britain. Published by Oxford University Press, Forestry, 77: 422-430.

Muukkonen, P. M . R., R. Laiho, K. Minkkinen, H. Vasander, and L. Finér. 2006. Relationship between biomass and percentage cover in understorey vegetation of boreal coniferousforests. Silva Fennica 40: 231-245.

Nowak, D. J. 1994. Atmospheric carbon dioxide reduction by Chicago's urban forest. In: McPherson, E. G., Nowak, D.J. and Rowntree, R. A. eds. Chicago's urban forest ecosystem: results of the Chicago Urban Forest Climate Project. Gen. Tech. Rep.NE-186. Radnor, PA: U.S. Department of Agriculture, Forest Service, Northeastern Forest Experiment Station.

Orwa C, A. Mutua, R. Kindt, R. Jamnadass, S. Anthony. 2009. Agroforestree Database:a tree reference and selection guide version 4.0 (http://www.worldagroforestry.org/sites/treedbs/treedataba ses.asp)

Pacala, S.W., G.C. Hurtt, D. Baker and others. 2001. Consistent land- and atmosphere-based U.S. carbon sink estimates. Science 292: 2316-2320

Patenaude, G. L., R. Milne and T. P. Dawson.2005. Synthesis of remote sensing approaches for forest carbon estimation: Reporting to the Kyoto Protocol. Environmental Science \& Policy, 8: 161-178.

Pearson, T.R., S.L. Brown, R.A. Birdsey.2007. Measurement guidelines for the sequestration of forest carbon. U.S.: Northern research Station, Department of Agriculture.

Peter, S., J. Raison, H. Keith, P. Ritson, et all.2002. Protocol for Sampling Tree and Stand Biomass. National Carbon Accounting System Technical Report No. 31
Pongsak-Sahunalu and Wiratana-Tanpibal .1985. Species trials of some terrestrial plants on the tin mine spoils. Seminar on problems and trends to improve mining area, Kasetstar University, Bangkock, Thiland.

Sanquetta, C.R., A. P.D. Corte and F. da Silva. 2011. Biomass expansion factor and root-to-shoot ratio for Pinus in Brazil. Carbon Balance and Management: 6:6. Published online 2011 Sep 24. doi: 10.1186/1750-0680-6-6.

Schulp, C., G. Nabuurs, P. Verburg and R. de Waal. 2008. Effect of tree species on carbon stocks in forest floor and mineral soil and implications for soil carbon inventories. Forest Ecology and Management 256: 482-490.

Sierra, C., J.del Valle, S. Orrego, F. Moreno, M. Harmon, M. Zapata, G. Colorado, M. Herrera, W. Lara and D. Restrepo. 2007. Total carbon stocks in a tropical forest landscape of the Porce region, Colombia. Forest Ecology and Management 243:299-309.

Smith, P. 2004. Soils as carbon sinks: the global context. Soil Use and Management 20:212-218.

Snedecor, G. and W. Cochran .1974. Statistical Methods. Sixth Edition. Iowa State University Press. Ames. Iowa. USA.

Sohial, A., A. Ahmad and S. M. Nizami .2014. Assessement of Biomaass Expansion Factor of Picea Smithiana (WALL) Boiss. International Journal of Scientific \& Engineering Research, 5:ISSN 2229-5518.

Swamy K.R., H. Shivanna, P. Surendra, K.S. Channabasappa and A.G. Koppad. 2011. Carbon stocking through shelterbelt tree species in Haveri District .My Forest, Sep.,47:175-181.

Timothy R.H.,S. Brown and R. Birdsey.2007. Measurement Guidelines for the Sequestration of Forest Carbon. USDA Forest service 11 Campus blvd suite 200, Newtown square PA 19073-3294. http://www.nrs.fs.fed.us/

UNFCCC .1997. Kyoto Climate Change Conference -JapanDecember 1997.

Van Deusen, P., F.A. Roesch and I. Sampling. 2011. Sampling a tree for total volume, biomass, and carbon. Journal of Forestry 109: 131-135.

Warnasooriya, W.M. and T. Sivananthawer.2016. Growth Performance and Carbon Accumulation of Khaya (Khaya senegalensis) in Sri Lanka Tropical Agricultural Research . 27:253- 264

Yunjian L. , X. Wang, X. Zhang, Y. Ren and H. Poorter. 2013. Variation in biomass expansion factors for China's forests in relation to forest type, climate, and stand development. Annals of Forest Science 70:589-599. 


\section{الملخص العربي \\ تقدير المخزون الكربونى لبعض أنواع الأثجار والتربة في مزرعة سير ابيوم \\ نشوى حسن محمد، هانى الكاتب}

اقيمت تجربة حقلية فى غابة سبيرابيوم التى تروى بمياه والكربون المخزون فى أنشجار الكازوارينا بليها الكـافور

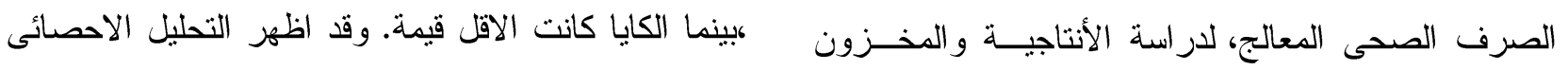

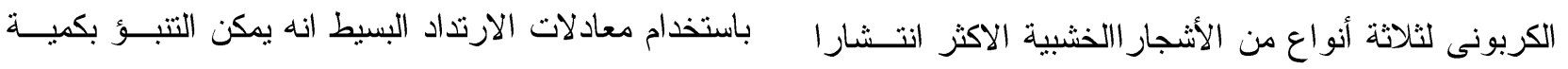

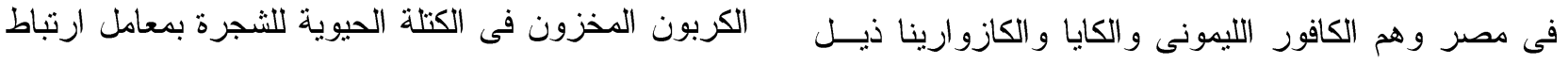

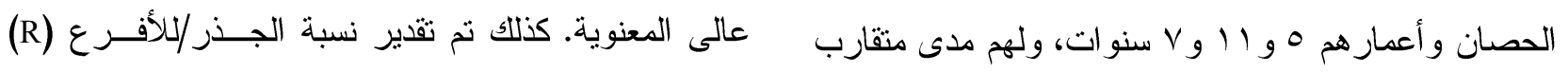

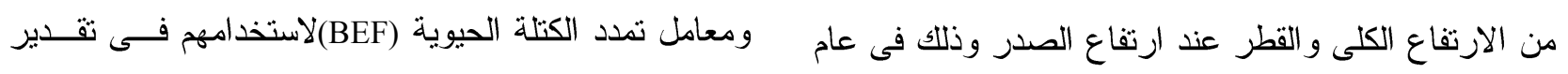

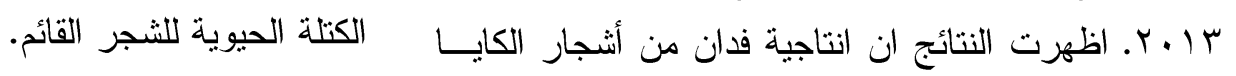

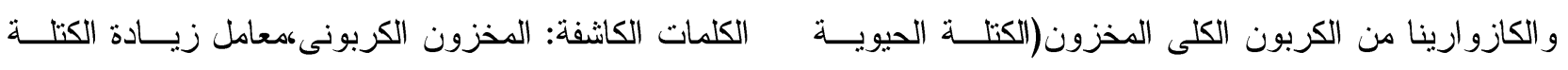

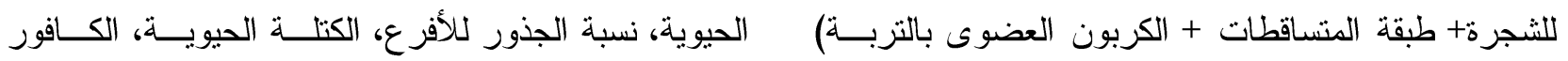

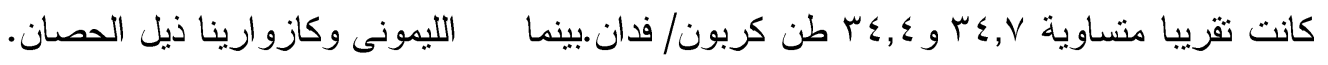

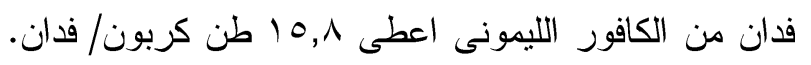

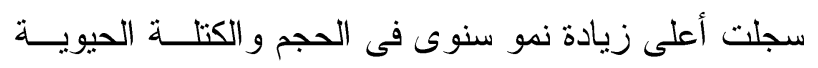

